\title{
Observations on the embryonic and early post-embryonic development of Rossia macrosoma (Mollusca, Cephalopoda)
}

\author{
S. von BolETZKY \& M. V. von BOLETZKY \\ C.N.R.S., Laboratoire Arago; Banyuls-sur-Mer, France
}

EXTRAIT: Observations sur le développement embryonnaire et postembryonnaire de Rossia macrosoma (Mollusca, Cephalopoda). Des pontes de Rossia macrosoma ont été récoltées au large de la côte catalane (Méditerranée occidentale). L'ultrastructure de la «coque» typique de l'oeuf de cette espèce est décrite. Le développement embryonnaire a été suivi à une température constante de $15^{\circ} \mathrm{C}$. L'embryogenèse est brièvement décrite, des stades importants sont représentés par des Figures. Quelques processus de l'organogenèse sont décrits et discutés en détail, tout en soulignant la dynamique de l'embryogenèse. L'importance du réseau de lacunes sanguines entourant le sac vitellin interne, pour le transport de matériel nutritif vers l'intérieur de l'hépatopancréas, est mise en évidence. L'éclosion se fait en principe comme chez les autres décapodes (action de «l'organe de Hoyle»), mais la rupture de la «coque» externe résulte, en plus, de la pression appliquée par l'animal; le «rostre» musculaire pourrait y jouer un rôle important. Des animaux éclos ont été élevés en laboratoire, pendant plusieurs mois, sous différents régimes de température et de luminosité. Les observations sur la croissance et le comportement sont comparées avec d'autres résultats obtenus en laboratoire et avec des données indiquées dans la littérature.

\section{INTRODUCTION}

Cephalopods are more commonly referred to as cuttlefish, squids and octopods, which correctly indicates members of the orders Sepioidea, Teuthoidea and Octopoda, respectively. There is, however, some terminological confusion with the so-called "sepiolid squids", decapods that are, in some respects, more similar to octopods than to squids, but in fact are cuttlefish. This confusion is one expression of the intriguing situation of the Sepiolidae. They form the most varied family among the Sepioidea, counting more than a dozen genera, divided into three sub-families. Among these, the apparently most archaic one is that of the Rossiinae, and they are therefore particularly interesting for investigations on the development, comparative morphology, taxonomy and phylogeny of the whole group (cr. BoLETzKY 1970a, 1971).

In his great monograph on the cephalopods of the Gulf of Naples, NaEF (1923, 1928) presented a comprehensive study of the Sepiolidae. As for their embryonic development, the lack of sufficient material accounts for a somewhat fragmentary 
description, particularly in the case of Rossia, only a few remarks being made on single developmental stages of $R$. glancopis and $R$. macrosoma.

The purpose of the present paper is to give a survey of the embryonic development of $R$. macrosoma (Delle ChIAJE), excluding a detailed description of organogenesis that is actually planned in the greater scope of a comparative study of sepiolid development. The questions raised and discussed here in detail refer to a few problems of general importance.

We also include in this paper some observations on the post-embryonic development, showing that $R$. macrosoma can be reared in the laboratory. In recent years, some sepiolids have become standard objects of laboratory culture (CHOE 1966; BoLETZKY et al. 1971; ARNOLD et al. 1972). Because of its comparatively large adult size and long development, Rossia will be less suitable, for many experiments, than the smaller Sepiolinae, but will serve as a valuable reference in comparative studies.

\section{MATERIAL AND METHODS}

Egg masses of Rossia macrosoma were obtained by bottom trawling at depths between 180 and $200 \mathrm{~m}$, off the coast of Catalonia (Western Mediterranean). The bulk of eggs used in this study was collected in late July and early August, 1971.

The egg masses with their substratum (bivalve shells) were kept in tanks with running sea water. Samples of eggs were taken at regular intervals for determination of the embryonic stages in the different egg masses, for microscopical observation in vivo and after fixation, and for histological investigation.

Embryos and juvenile animals were preserved in Bouns's or CARL's fixative, also in SUSA or formalin, embedded in paraffin and processed for light microscopy. Egg cases were preserved in $1 \% \mathrm{OsO}_{4}$ in sea water and embedded in Epon; of this material, thick and thin sections were cut on an ultramicrotome. The embryos shown in the figures were either photographed alive, or drawn and photographed after fixation and dissection (in general, the bulk of yolk was cut away with a razor blade). In early embryos, the actual thickness of the tissue shows up well when the preparation is illuminated from below, the yolk being very translucent.

Hatched animals were kept in opaque tanks (501) with running sea water; they were fed live prawns (Leander serratus). Light and temperature conditions were varied for different batches.

\section{RESULTS}

\section{Structure of eggs and egg masses}

The globular eggs of Rossia macrosoma are deposited singly on a solid substratum and on previously laid eggs (RAcoviTZA 1894), as in Sepiolinae; but in contrast to these (producing two layers of eggs, at the most), the eggs of $R$. macrosoma are piled up to large masses of about 20 to 80 eggs, characterized by a more or less compact "archi- 
tecture" (Fig. 1). We ignore whether the width of the spaces left between eggs (which varies among egg masses) is related to water motion and oxygen concentration at the site of spawning.
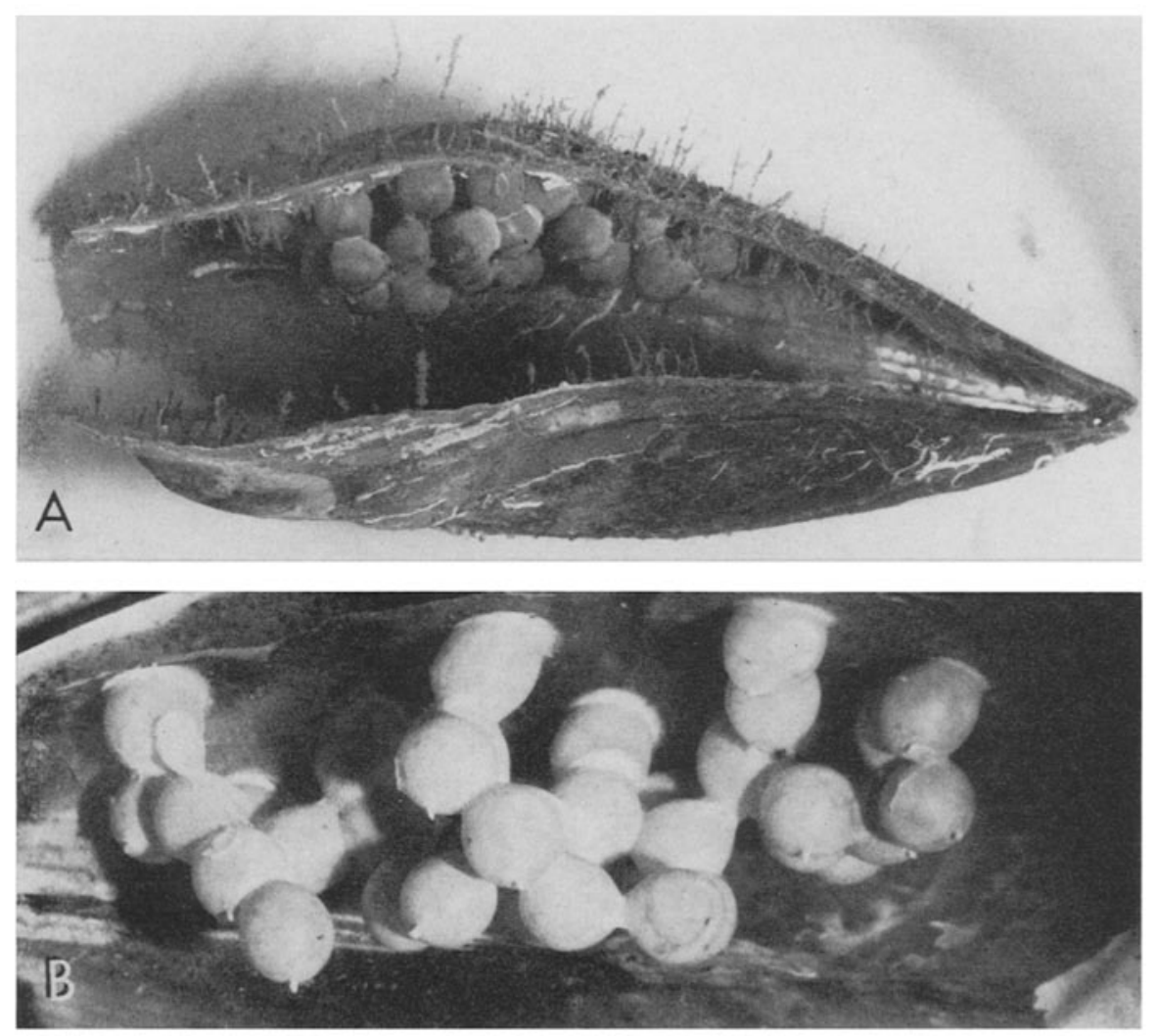

Fig. 1: Eggs of Rossia macrosoma, deposited in empty Pinna shell. Note difference in density between $A(1 / 2$ natural size) and $B$ (natural size)

The prevailing substratum for attaching eggs appears to be empty shells of Pinna pectinata; rarely, eggs are found on Avicula, as those of certain Sepiolinae, or on other substrata. The distribution of organisms found on the Pinna shells shows that these were not in the vertical position typical of the living animals, but that they were lying on the ground and that the eggs were attached to the ceiling of the shelter formed by the empty shell.

The diameter of eggs may vary, among egg masses, between 9 and $11 \mathrm{~mm}$; it is rather constant within an egg mass. The young embryo, with its large yolk mass $(6.5 \times 5 \mathrm{~mm})$, is tightly enclosed in the chorion (Fig. $2 \mathrm{~A})$ which, in turn, is wrapped in a coiled jelly band (JECKLIN 1934). The outer egg case surrounding the jelly envelope is a rigid sphere (RAcoviTZA 1894); its thickness is about $0.2 \mathrm{~mm}$. In contrast to all eggs known of other decapod cephalopods, the volume of the Rossia egg does not change 
during embryonic development. Consequently, the structure of the egg mass also remains stable.

During development of the embryo, the chorion swells, tightening the turns of the spiral jelly so that it forms, at late embryonic stages, a rather thin coat underlying the rigid egg case. This outer case is made up of a number of layers of different thickness and texture (Fig. 3). Layers are separated, throughout the egg case, by very dense
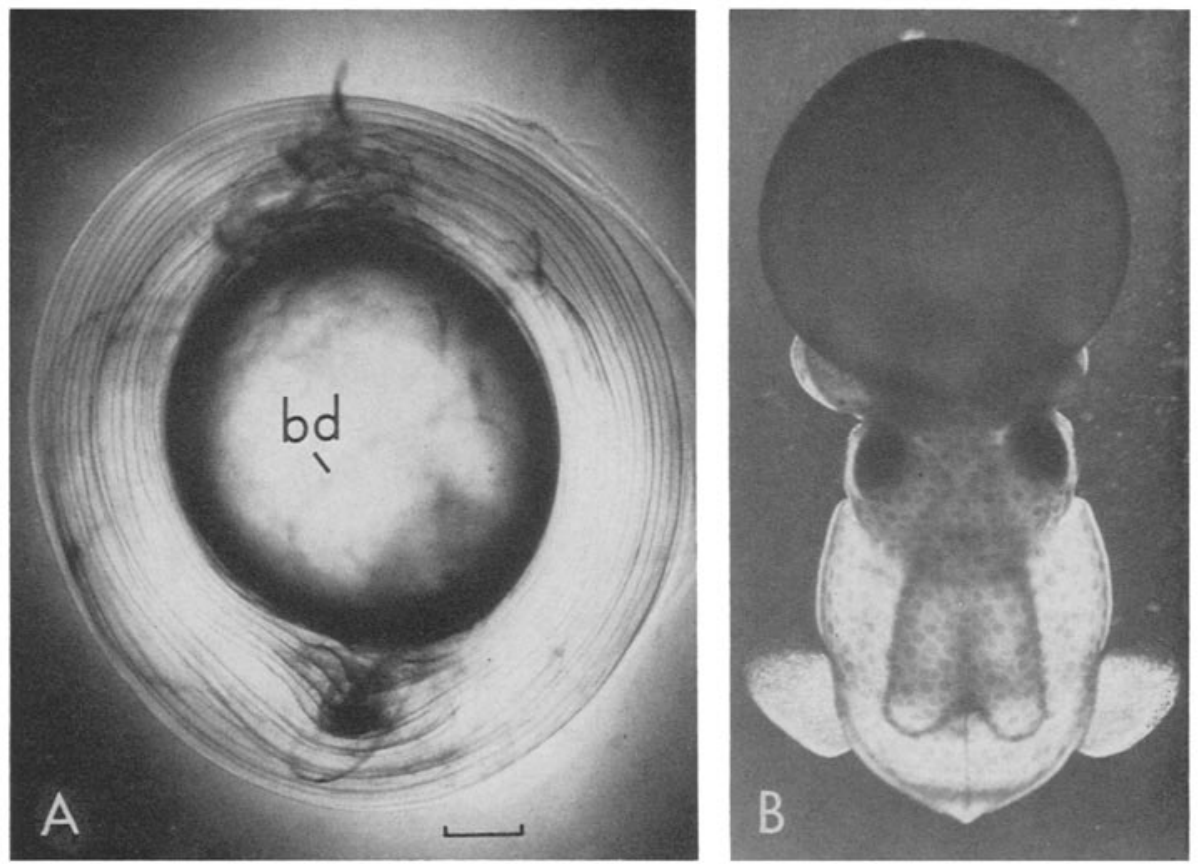

Fig. 2: Two developmental stages of Rossia macrosoma. A: embryo at stage IV-V, tightly enclosed in the chorion that is spirally wrapped by the gelatinous envelope; the outer egg case is removed. $B$ : fully developed embryo (nore chromatophores reacting to light) at stage

$X I X-X X$, still having a very large amount of yolk. The scale $(1 \mathrm{~mm})$ is for $A$ and $B$

"membranes"; one such membrane covers the outer coating. The thin outer layers show a very fine texture, which becomes suddenly coarser in the following layers. The layer next to the jelly is characterized by large cavities. They contain "colonies" of bacteria that, by sticking together at one end, form "brushes" (in vivo observations). Probably, they are included during egg laying; a later penetration is very unlikely.

At present, we entirely ignore the function of these bacteria, as well as the meaning of the differences observed in the texture of the egg case. The general structure suggests that the combination of different layers provides optimal stiffness.

Fig. 3: The fine structure of the outer (rigid) egg case of Rossia macrosoma. At the lower right a thick (cross) section, stained with basic fuchsin (scale $0.1 \mathrm{~mm}$ ). 'The electron-micrographs correspond to the areas indicated. Note bacteria in $C$ 

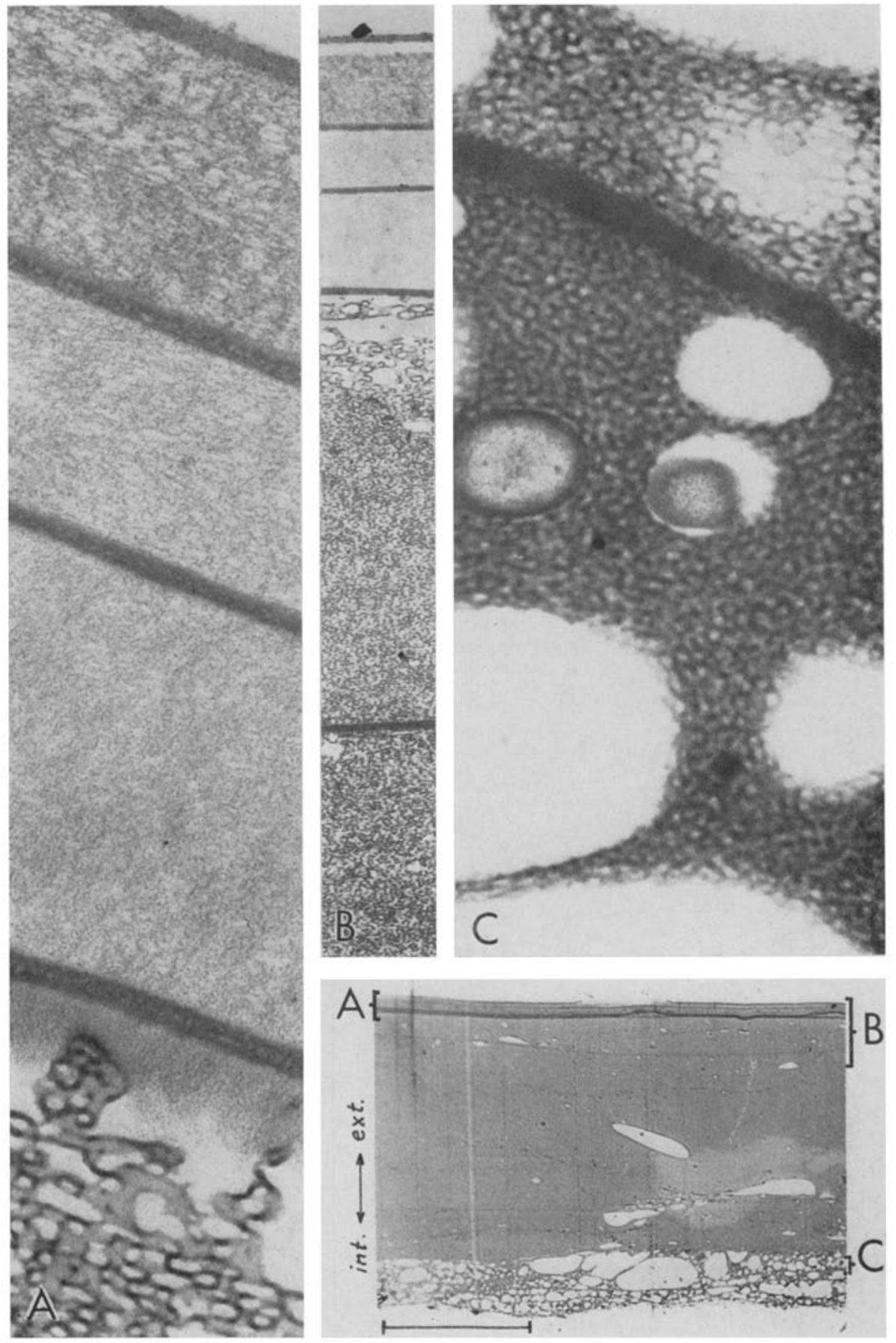

Fig. 3 
In contrast to the egg case of Sepia, for instance, the outer egg case of Rossia macrosoma does not decay for several months after hatching of the young animals.

An investigation of the physiological role, during the embryonic development, of the structure of the egg case and of the bacteria inhabiting it might shed light on various problems of the biology of decapod embryos (Jeckuin 1934).

Another open question is how these egg cases are built by the female $R$. macrosoma. It is known that the nidamental glands produce the gelatinous band which is spirally wrapped around single eggs, as in all Sepioidea, or around a string of eggs, as in Teuthoidea. But we do not yet know exactly how the outer coating of eggs or egg strings is formed.

Course of embryonic development at a constant temperature

An egg mass that had apparently been laid a short time before it was collected (the eggs were at the first cleavage) made the establishment of a complete developmental curve possible. Figure 4 shows developmental stages (according to NAEF 1923) plotted against time, for a constant temperature of $15^{\circ} \mathrm{C}$. The morphological features

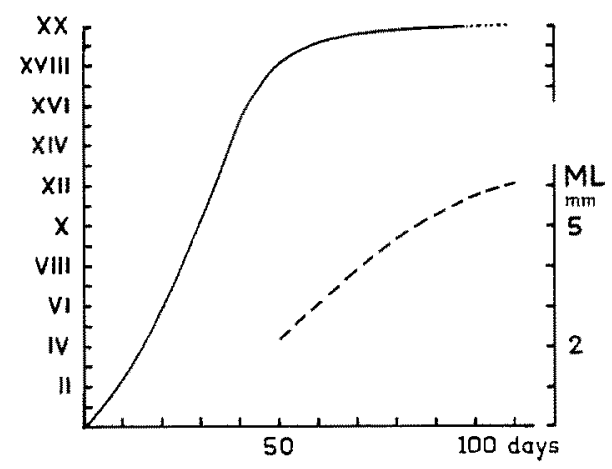

Fig. 4: Course of embryonic development of Rossia macrosoma, at $15^{\circ} \mathrm{C}$. Developmental stages of NAEF (1923) and, for last stages, dorsal mantle length (broken line at lower right) plotted against time. Dotted part of stage/time curve indicates period of "normal" hatching, which possibly extends further to the right, under natural conditions

observed in $R$. macrosoma roughly correspond to NAEF's characterization of the development of Sepia. Our graph represents the optimal rate of development (at $15^{\circ} \mathrm{C}$ ) which is, according to our observations on several species, most reliable (slower development may be due to oxygen deficiency caused by the experimental conditions). At $15^{\circ} \mathrm{C}$, the rate of development, in terms of NEAF's stages, rises from initially one stage per five days to a rate twice as high at the beginning of organogenesis (stage VI), remains fairly constant throughout organogenesis up to stage XV when the inner yolk sac is secondarily enlarged by yolk transfer (PoRTMAnN 1926), and then rapidly decreases. The length of time between stage XVIII (large external yolk sac) and stage $\mathrm{XX}$ (external yolk sac almost entirely taken in by the animal), during which growth 
and organ differentiation take place, is about equal to the time of attaining stage XVIII. This is typical of large cephalopod eggs (FIoronI 1964).

Eggs kept at a constant temperature of $20^{\circ} \mathrm{C}$, from stage VI onward, did not develop normally, suggesting that $R$. macrosoma is fully adapted to the low temperatures of its natural habitat (MANGOLD-WIRZ 1963).

\section{Early stages of embryogenesis}

The early stages shown in Figure 5 represent a few steps of the typical meroblastic development of the embryo, from the first cleavage (A) through stages of mesoderm formation (B), retraction of yolk cells ("blastocones" forming the yolk syncytium) under the blastodisc (C) on to stage IV (D) when the embryo is separated into an actual organogenetic part and the peripheral area forming the transitory yolk sac (cf. NAEF 1923). The cell material that will be involved in organogenesis, is already differentially arranged, showing a bilateral symmetry. This is meaningful in view of the process of organ determination, the mechanism and timing of which is actually debated (ARnold 1965b, 1968, Marthy 1972a, b).

The aspect of the entire living egg, at a slightly later stage, is given in Figure $2 \mathrm{~A}$. The portion of the yolk mass that is covered by the "cap" of the embryo (including the rudimental yolk envelope), is comparatively small. Growth of this embryo cap comprises tissue proliferation and spreading, up to stage VII when about $3 / 4$ of the yolk mass are covered (closure of the yolk envelope occurs at stage VIII-IX).

A comparison of Figure $5 \mathrm{D}$ and $\mathrm{E}$ illustrates the distribution of material lying in symmetrical "stock areas" (stage IV) into "clouds" containing recognizable organ rudiments (stage VI). While the surface of the embryo continues to increase in size, these rudiments become more distinct at stage VII (Fig. 5 F, $6 \mathrm{~A}$ ).

\section{Stages of organogenesis}

The organogenetic processes observed in Rossia macrosoma do not greatly differ from those described of other decapod cephalopods. A general idea of the embryogenesis can be drawn from Figures 5 to 12, which allow also a comparison of the developmental stages of other species as described by earlier authors (NAEF 1923, Arnold 1965a, Fields 1965, Lemaire 1970, Natsukari 1970, Arnold et al. 1972). We will return, in the discussion, to the problem of the dynamics of organogenesis. The present chapter is limited to a few observations on several organ systems.

A r m - f u n e l c o m plex. The two crescent-shaped areas lying on either side of the mantle rudiment, at stage VI (Fig. $5 \mathrm{E}$ ), differentiate into the gills and the mesodermic complexes attached to them (coelom, kidneys, central circulatory organs), including the "mesentodermic" mid-gut complex; the dorsal parts form the funnel pockets. At the posterior margin, an ectodermic thickening forming a transversal band becomes very distinct at stage VII (Fig. 5 F). NAEF (1928) pointed out that the funnel organ (see also Froroni 1962) appears at the site of this thickening, which he referred 
to as "Gürtelband". He also emphasized that the paired rudiments of the funnel tube are not included in the crescent-shaped complexes, but that they separate from the arm complex. This important process is particularly distinct in Rossia (Fig. $5 \mathrm{~F}, 6 \mathrm{~A}$ ). Between stages VII and VIII, the rudiments of the funnel tube split off the brachial complex and are then more closely attached to the rudiments of the funnel pockets (Fig. 6 B).

This "shifting" is part of the general contraction of the embryo cap, starting in its central part, which marks the beginning of the actual morphogenesis. Different rudiments now take shape by tissue concentration (along with mitotic activity) and folding.

The arm complex undergoes the same morphogenetic process somewhat later. During concentration of the arm rudiments, a little groove appears in the middle of each knop (Fig. 6); this was considered by NAEF (1923) as a duplication of the rudiments. These grooves only indicate the formation of the brachial veins. Between stages IX and X, the brachial "clasp" also contracts and joins the cephalic complex (cf. Fig. $6 \mathrm{C}$ and $\mathrm{D})$.

Sucker rudiments appear at stages IX-X. Their number increases by continual formation of distal rudiments that are uniserial. The biserial and finally quadriserial arrangement is brought about by subsequent "crowding" of the more proximal rudiments (Fig. 9).

Stomodaeum and mid-gut complex. Earlier authors have described the formation of the stomodaeum, its invagination (together with secondary invaginations: salivary glands, radula) and its terminal growth leading to the formation of the oesophagus. According to KorscheLT (1892) and MEISTER (1972), the latter would meet the mid-gut at the posterior end of the yolk mass. NAEF (1923) noted, however, that the mid-gut complex in fact forms a ring surrounding the inner yolk sac and that the oesophagus fuses with it on the dorsal side. We have re-investigated this process in Octopus vulgaris (BoLETZXY 1967) and found that the ectodermic oesophagus is very short at first, whereas the mid-gut extends far anteriorly on the dorsal surface of the yolk mass. This is also true for decapods (BoLETzKY 1970b), the paired dorsal limbs of the mid-gut extending beyond the anterior border of the mantle rudiment, although they do not give rise to the formation of a crop as in octopods.

The invagination of the stomodaeum occurs during the phase of contraction (Fig. 6 B-D). An actual fusion of the posterior end of the stomodaeum with "the" anterior end of the mid-gut rudiment is not recognizable, however. This is due simply to the fact that the limbs of the latter do not show a distinct anterior end. The epithelium is well defined all along to the anterior border of the mantle rudiment, but then "disintegrates" anteriorly. At stage $\mathrm{X}$, rather scattered nuclei can be seen, on histological sections, to form a continuation of the mid-gut epithelium, extending to the posterior end of the stomodaeum. The shape of the latter suggests that these cells tend to draw the stomodaeum posteriorly, presumably along with arranging themselves into a more compact epithelial structure. Figure $6 \mathrm{D}$ shows a stage slightly more advanced than in Figure 11. The communication formed by these supposedly contracting cells becomes narrower, the limbs of the mid-gut unite, and the posterior end of the stomodaeum tapers off. Since the fore-gut is stretched out over the yolk surface, 


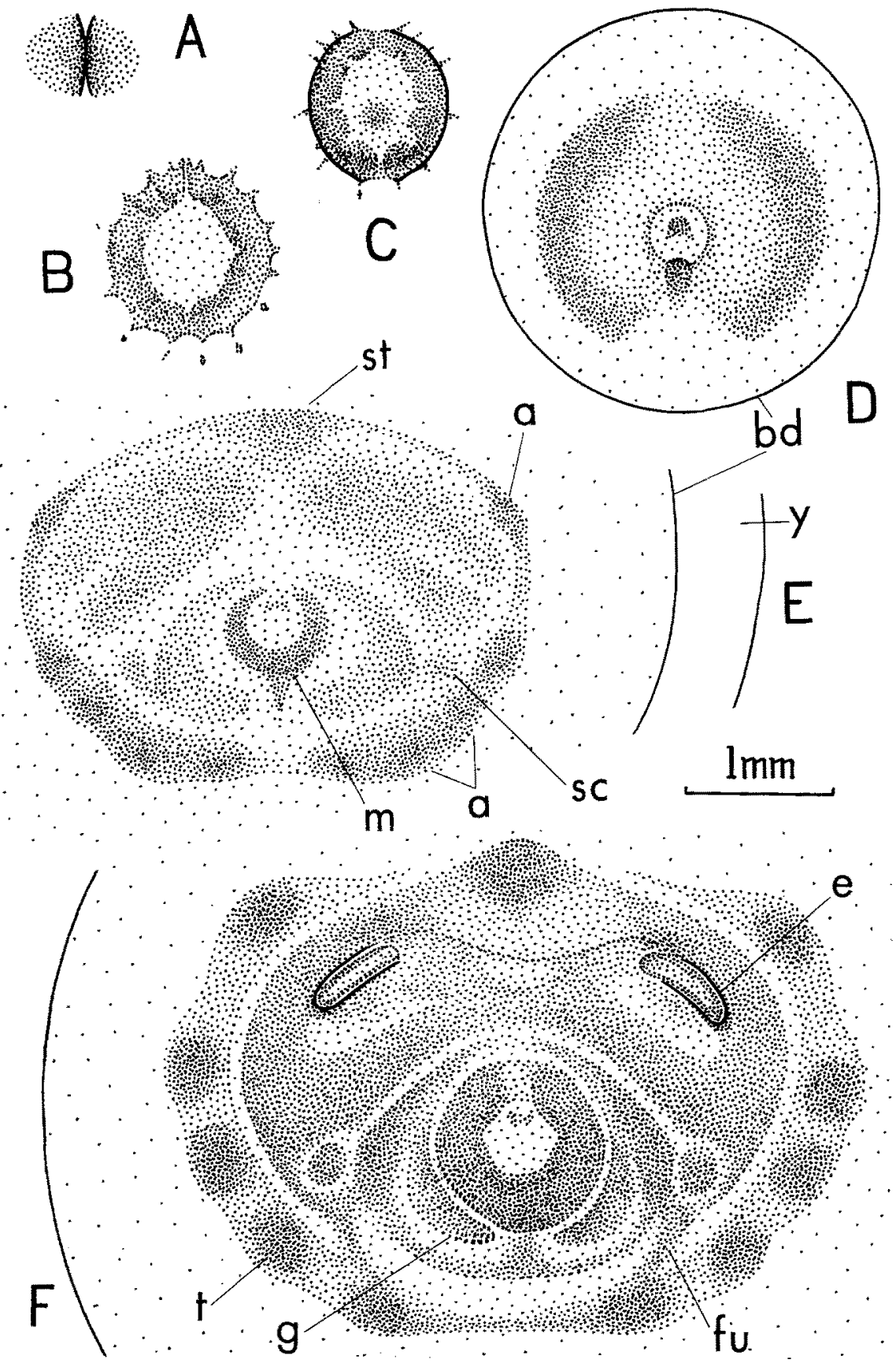

Fig. 5: Early developmental stages of Rossia macrosoma (from preserved specimens). A: 2-cell stage, $B$ : stage II, $C$ : stage II-III, $D$ : stage IV, $E$ : stage VI, $F$ : stage VII. Note the increasing spread of the embryo from $D$ to $F$ 


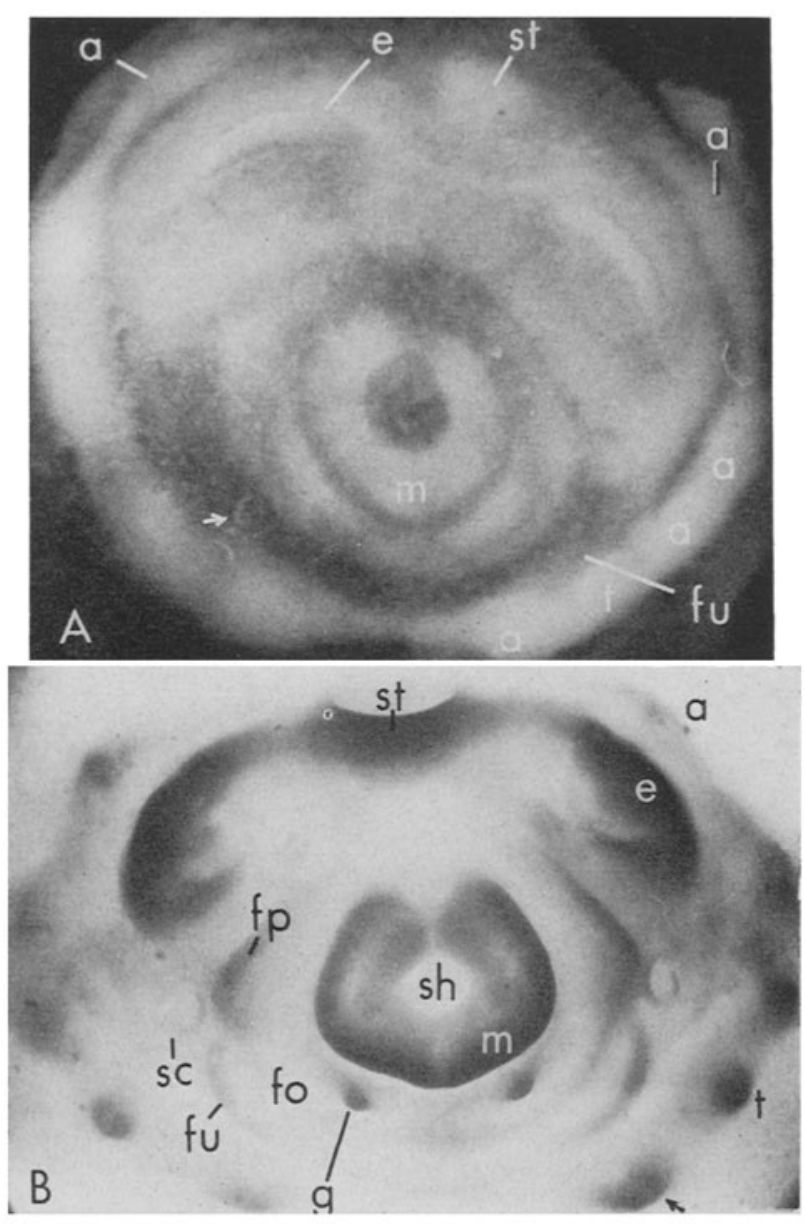

Fig. $6 A, B$ : Stages of organogenesis of Rossia macrosoma (from preserved specimens; same magnification in $A-D ; A$ : incident, $B-D$ : transmitted light). $A$ : stage VII (the blastodisc adheres to the chorion, arrow marks micropyle; the yolk is completely removed), $B$ : stage VIII

we have not been able to observe, on histological sections, the appearance of the continuous lumen; it becomes distinct around stage XIII, when the mid-gut complex is closed towards the yolk (cf. BoLETZKY 1967).

Although there is no doubt as to the large extent of the mid-gut rudiment, the problem of the primary contact (in structural and topographical terms) between midgut and stomodaeum, at present remains unresolved.

Shell sac and fins. One of the typical features of the Sepiolidae is the extreme reduction of the shell (NAEF 1923). The embryonic shell sac is, however, as large as in other decapods (unlike the extremely small shell sac of octopod embryos). The differentiation of the actual shell gland epithelium is limited to the prospective area of shell formation, in the anterior part of the sac (Fig. 11), as in Sepiola (BolETZKY 


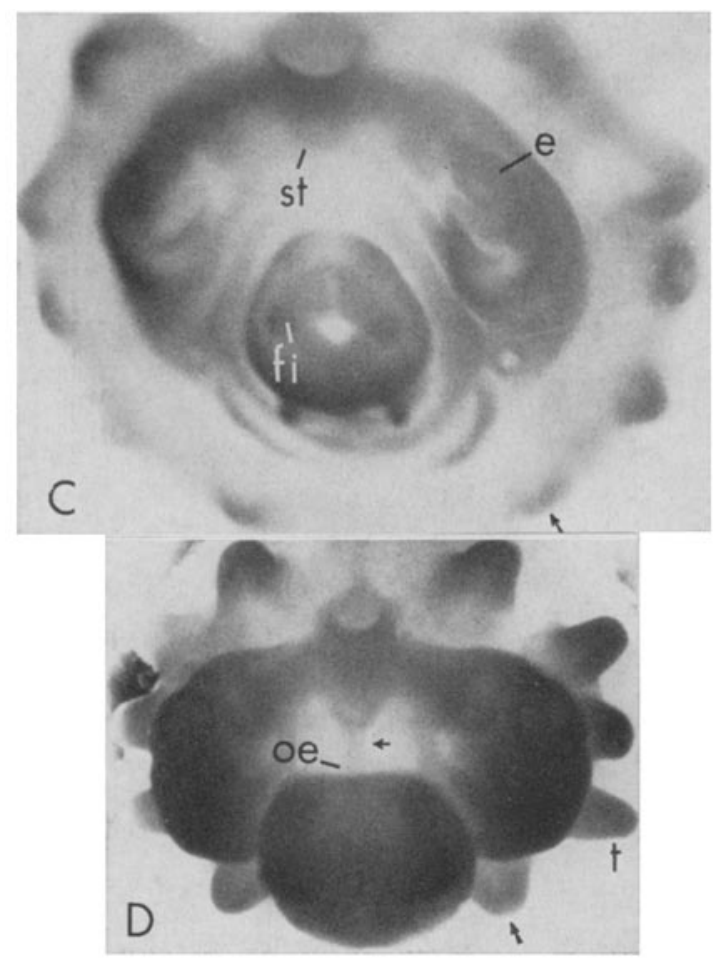

Fig. $6 C, D$ : Stages of organogenesis of Rossia macrosoma. C: stage IX, D: stage X, small arrow marks posterior end of stomodaeum. Note contraction of the embryo leading to organ "assembly". Arrows at the lower right, in $B-D$, indicate arm vein

1964). This part transforms, in the course of the differentiation of the broad, free dorsal mantle border, into an increasingly narrow, flattened tube (Fig. 7 G, cf. SpIEss 1972). The primary (ventral) shell epithelium becomes active around stage $X V$, when the dorsal adhesive organ of the mantle also takes shape (NAEF 1923, Fig. 323).

Following the muscular differentiation in the dorsal part of the mantle, the remaining sac is separated from the actual shell gland; it splits again into two lateral pockets, their outer walls form the basal cartilages of the fins. The close morphological relationship between the fins and the lateral parts of the original shell sac is already distinct at stage IX when the rudiments of the fins appear (Fig. $6 \mathrm{C}$ ).

$\mathrm{V}$ en a $\mathrm{c}$ a va. The vena cava or vena cephalica of cephalopods splits posteriorly into two limbs, conducting the blood coming from the cephalopodium to the branchial hearts. The vena cava originally bifurcates at the anterior end of the hind-gut complex (intestine and ink sac) of the embryo. In sepiolids (among others), a secondary posterior communication is formed, later on, behind the intestine.

In a comparative study of the circulatory system of cephalopods, NAEF (1910) ascribed particular importance to the early appearance of this posterior communication in Rossia, which might indicate the ancestral character of this formation that is 

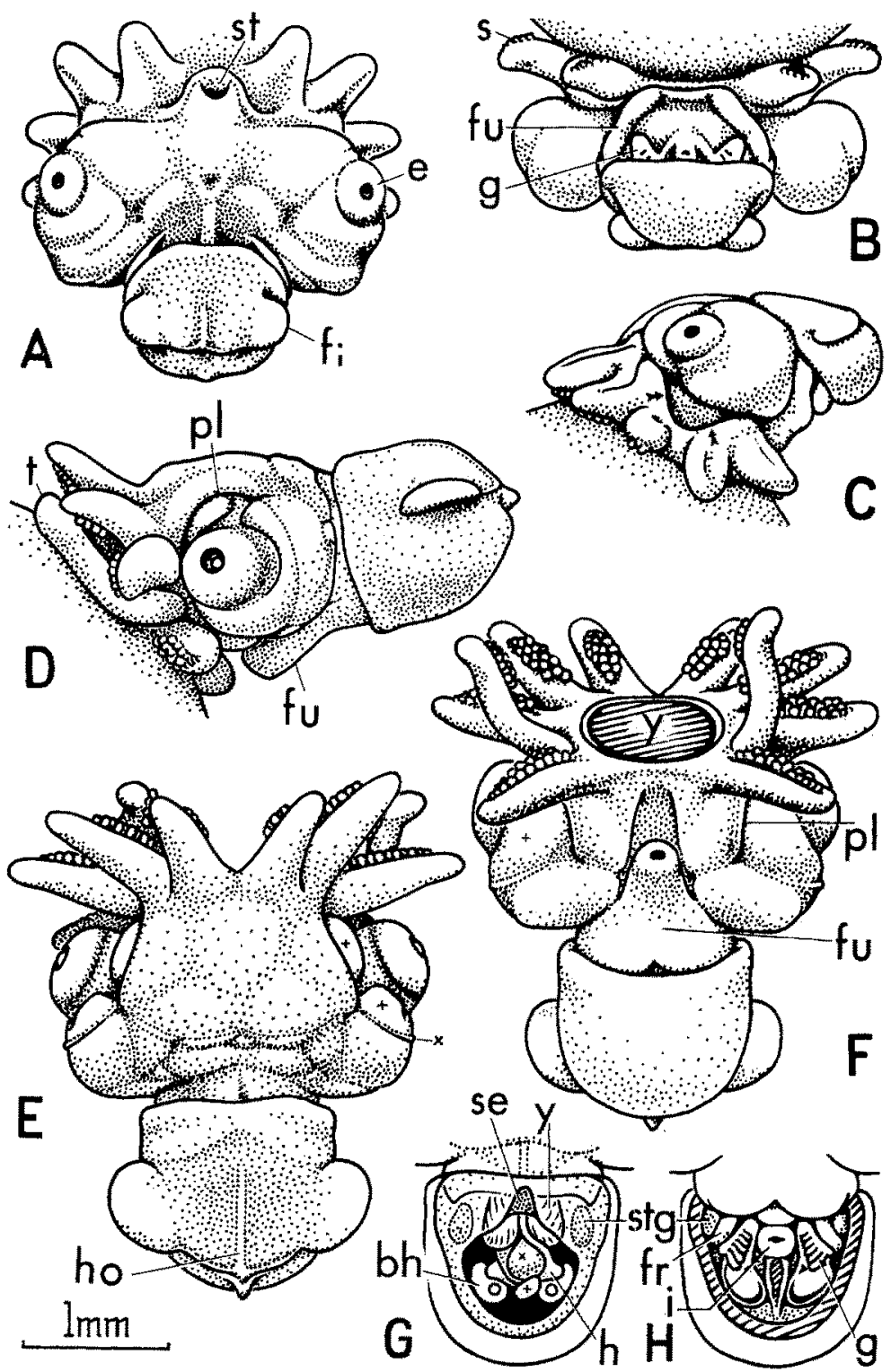

Fig. 7: Stages of later organogenesis of Rossia macrosoma (from preserved specimens), $A-C$ : dorsal, ventral and lateral view of stage XI, arrows in $C$ mark edge forming primary eye lid. $E-H$; stage XIV (outer yolk sac removed). Note the development of the arm bases that form the primary lid and also cover the mouth between the dorsal arms. X marks in $E$ the posterior communication of $\mathrm{pl}$, + indicates the ectodermic thickenings (forming the anterior chamber organ) that fixate the eye complex and also contain the eye muscles. The posterior end of the hatching gland (ho) lies on the muscular "terminal spine". $G$ is a dorsal view of the body, after removal of the integument; the "window" through which the inner organs are seen, is the large shell sac that is not yet replaced by the mantle muscle; $X$ is the stomach, on top of it the gonad.$+ H$ is a ventral view after dissection of the mantle 

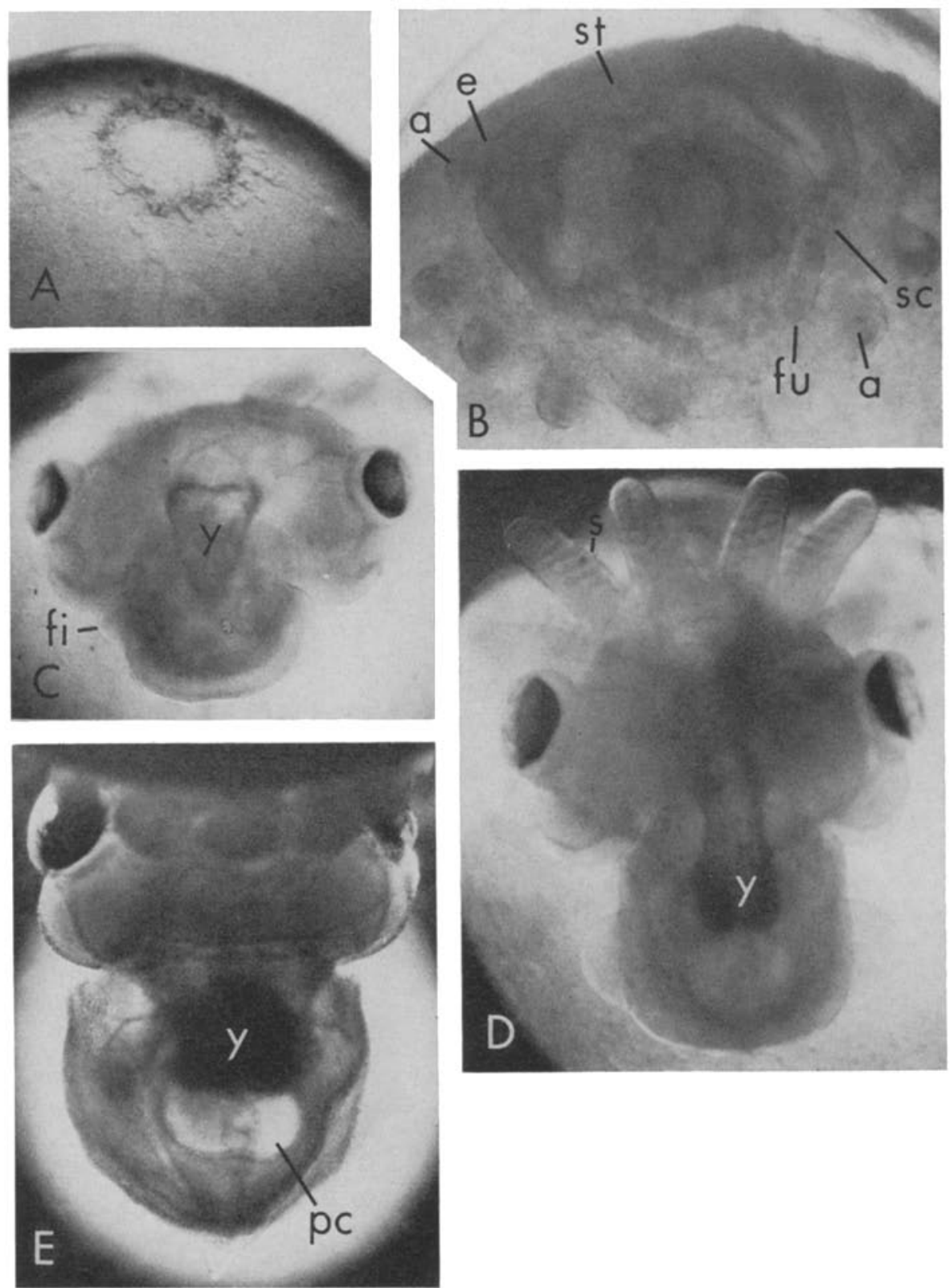

Fig. 8: Living embryos of Rossia macrosoma (same magnification in $A-D$ ). A: stage II, $B$ : stage IX, the yolk envelope now pulsates, pigmentation of the retina begins. C: stage XII, central circulatory organs begin slowly to pulsate. $D$ : stage XIV, slight contractions of the mantle and eye movements. E: stage XV, the first chromatophores (yellow) appear on the dorsal surface of head and mantle; pulsation of systemic heart and branchial heart is regular, but not yet coordinated; yellow concretions appear in the kidney. Ink secretion begins at stage XV-XVI 
also present in Nautilus. Injection of the circulatory system of living embryos as well as histological sections show, however, that in Rossia this communication is formed later than stage XVI (Fig. 12), although the limbs of the vena cava are in close contact with each other at early stages. Even in Octopus, the corresponding communication appears earlier than in Rossia (cf. BOLETZKY 1968).
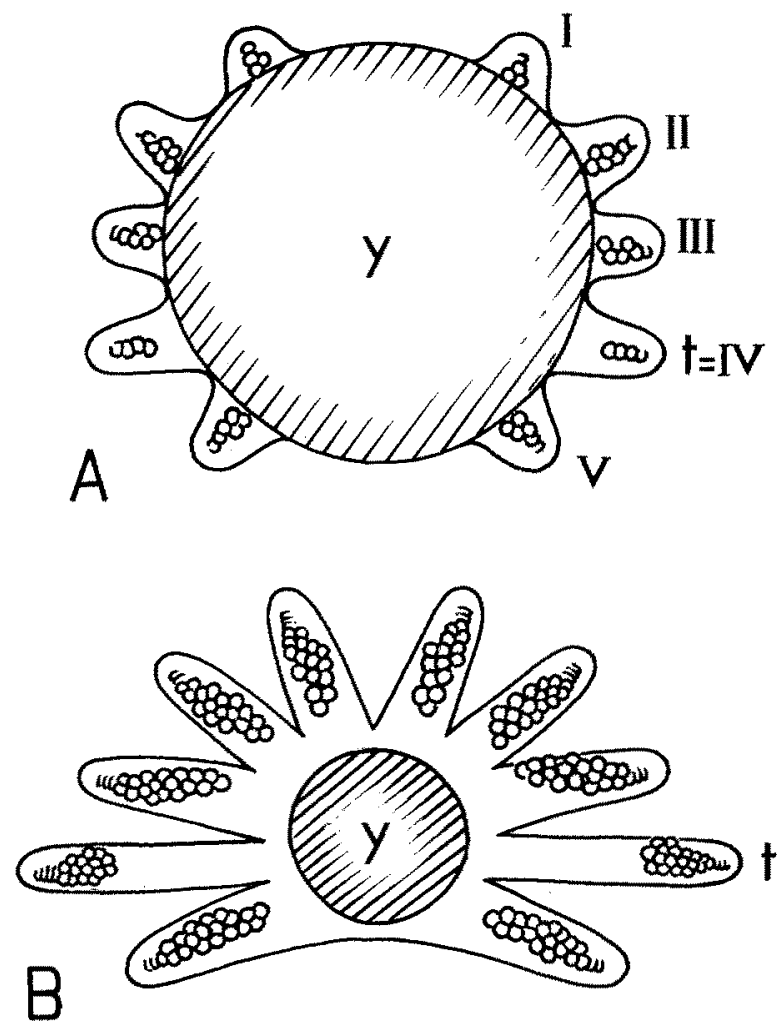

Fig. 9: Arrangement of sucker rudiments on the arms of Rossia macrosoma, at stage X-XI (A) and stage XIV (B)

\section{Later embryonic stages}

Yolk orga n. During organogenesis, only a small fraction of the yolk mass is absorbed by the yolk syncytium and passed, by means of the embryonic circulatory system, to the overlying tissue (PoRTMAnN 1926). The bulk of nutritive material thus remains to be absorbed during the later embryonic stages that are characterized by coordinated growth and differentiation of organs, resulting in an almost adult-like small animal a long time before hatching (Figs $2 \mathrm{~B}, 4,10$ ).

In contrast to Sepiolinae (NAEF 1928, ARNold et al. 1972), the outer yolk sac of Rossia is perfectly globular, at all stages. The shape of the inner yolk sac also differs from that found in other genera, as will be shown below. 


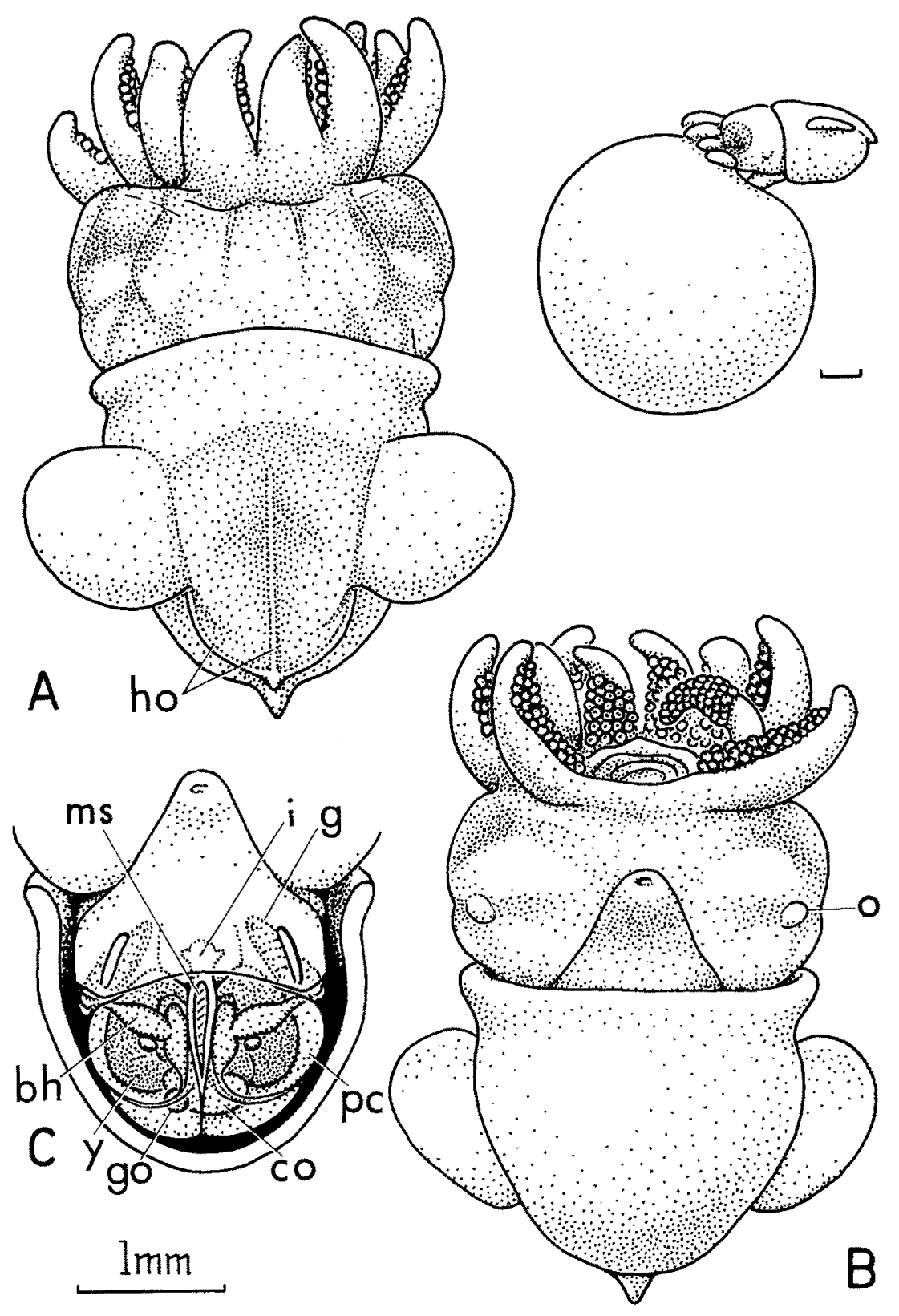

Fig. 10: Rossia macrosoma at stage XIX (from preserved specimen, chromatophores are not shown). $A$ : dorsal, $B$ : ventral view, $C$ : ventral view of visceral mass after dissection of mantle. At the upper right, a lateral view of the same specimen with its large outer yolk sac 
At stage XIV, the inner yolk sac is completely compressed by the organs of the head and the visceral mass (Fig. 8 D). Portmann (1926) described the yolk transfer from the outer to the inner yolk sac, at later stages, in Loligo vulgaris. This process is common to all known cephalopods except for the species in which the eggs are ex-m tremely small (Argonauta, Ommastrephidae). In these cases, the embryo encloses the entire yolk mass at early stages already (NAEF 1923).

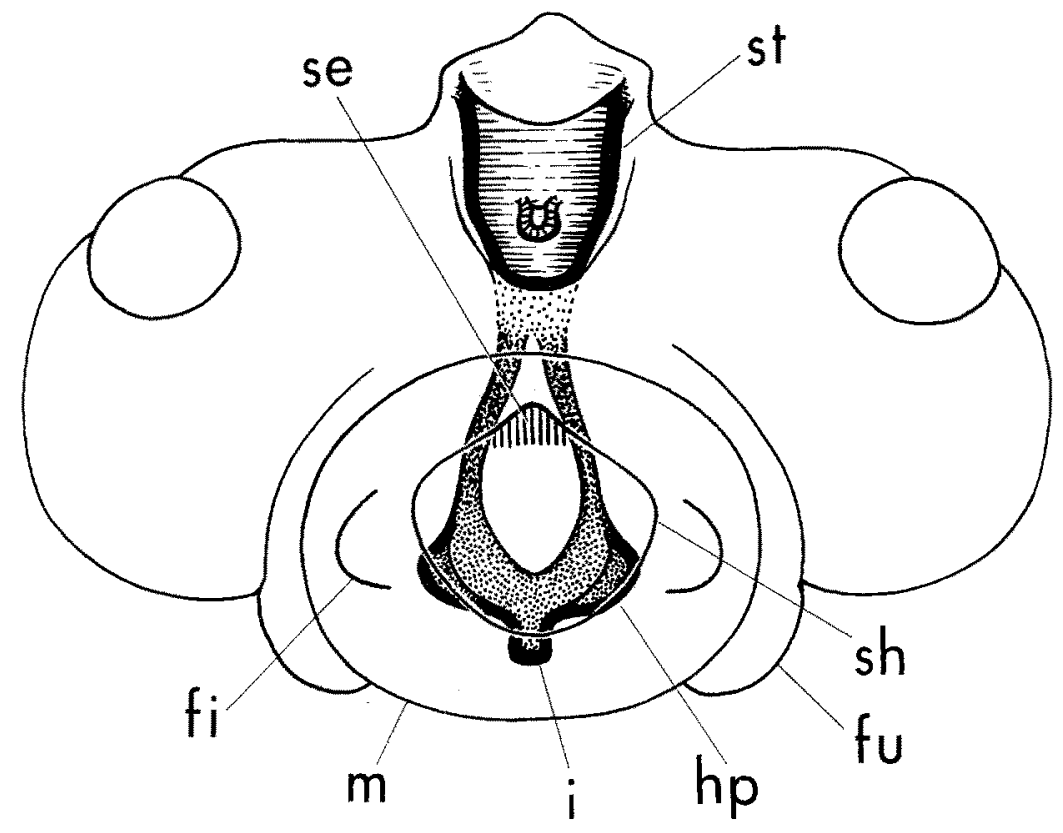

Fig. 11: Reconstruction of an embryo of Rossia macrosoma, at stage X (dorsal view, withour arm rudiments), showing the stomodaeum (with the secondary invagination forming the posterior salivary gland), the mid-gut complex and the shell sac (that is nearly closed)

The shape of the secondarily enlarged inner yolk sac differs among systematic groups (SACARRAo 1956). In sepiolids, its posterior part in general splits into four lobes (cf. ARNOLD et al. 1972) that are formed in close relationship to the mid-gut complex. In the Sepiolinae, these lobes are about equal in size and are arranged, in later embryonic stages, in the horizontal plane of the mantle complex. In Rossia, however, the "lateral" lobes are very inconspicuous so that the inner yolk sac appears as a bilobed organ (Fig. 2 B). This situation is interesting in view of the embryonic anatomy of Sepia, in which a four-lobed yolk sac develops from a situation corresponding to that persisting in Rossia (instead of the finger-like four lobes of Sepiolinae, two lobes are secondarily formed, in Sepia, by "segmentation" of the original lobes).

PORTMANN \& BidDer (1929) investigated the yolk absorption in Loligo and localized it, for later embryonic stages, in the hepatopancreas. According to these authors, nutritive material is transferred by cells of the liver that are in contact with 
the yolk sac, to the interior of the liver and then passes to the bloodstream through the "pancreas".

Our observations on Rossia macrosoma suggest that the network of blood vessels, to which the earlier sinus surrounding the inner yolk sac is transformed (PORTMANN 1926), has an important function as a collecting system. Injection of this system shows

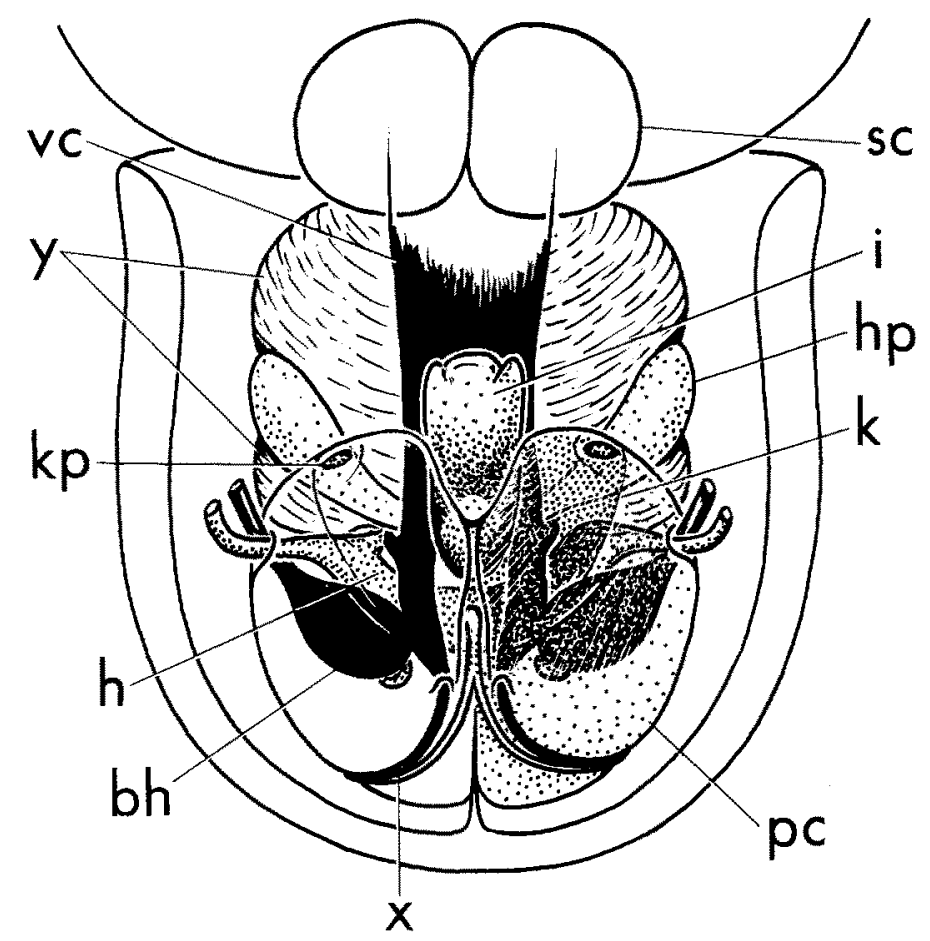

Fig. 12: Reconstruction of some organs of the visceral mass, at stage XV-XVI, in Rossia macrosoma. At left, the kidney and pericardium (communicating with one another under the kidney papilla) are represented as entirely transparent; at right, the kidney is marked by darker shading than the pericardium. $X$ marks the abdominal vein and artery running over the pericardium (that is secondarily unpaired, in contrast to the paired kidney sacs)

that the vessels enter the hepatopancreas between the hepatic tubules (Fig. 13). This observation raises the question whether the yolk syncytium remains the primary yolkabsorbing "organ" (cf. KoNOPACKI 1933), during the later stages when the hepatopancreas is in some way involved in the transfer of nutritive material. All animals had a considerable amount of inner yolk when they hatched.

$\mathrm{Hatch}$ ing. The mechanism of hatching, in some decapods and octopods, has been described in detail by ORELLI (1959). In Rossia macrosoma, the presence of a rigid outer egg case slightly modifies the process of hatching, in comparison to other decapods, although the secretory action of the hatching gland ("Hoyle's organ" Figs $2 \mathrm{~B}$, 7,10) is identical (WINTREBERT 1928). If the outer egg case of an animal ready to hatch is taken away, one can observe this action on the gelatinous envelope: the hatching 

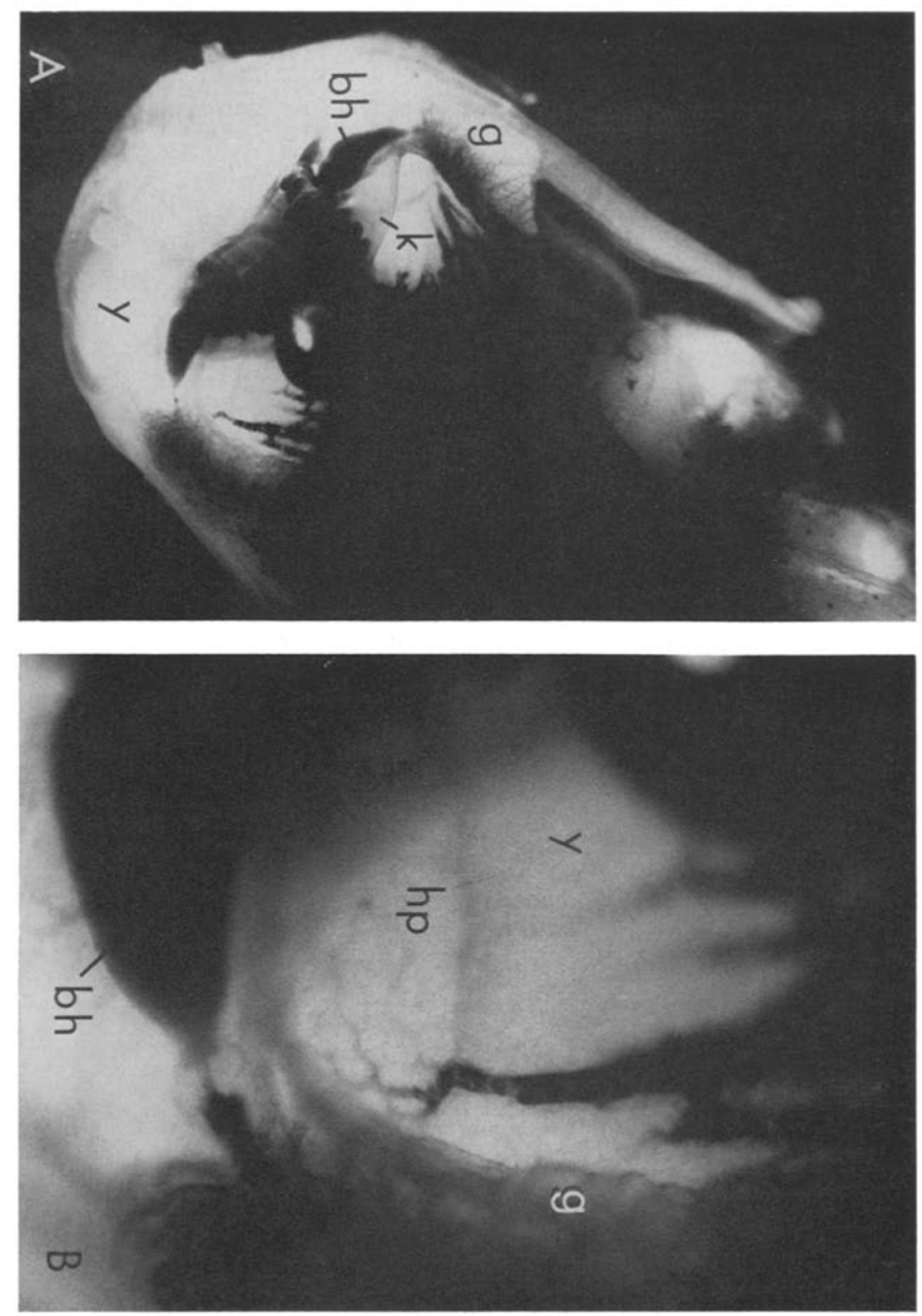

Fig. 13: Rossia macrosoma, not long before hatching. Injection of circulatory system reveals communication of yolk vessels with hepatopancreas ( $B$ detail of $A$ ). In this live preparation, only the largest of the lateral vessels are fully injected, two large medial yessels are covered by the vena cava. Besides these, there are numerous other yolk vessels entering the hepatopancreas all along its periphery 

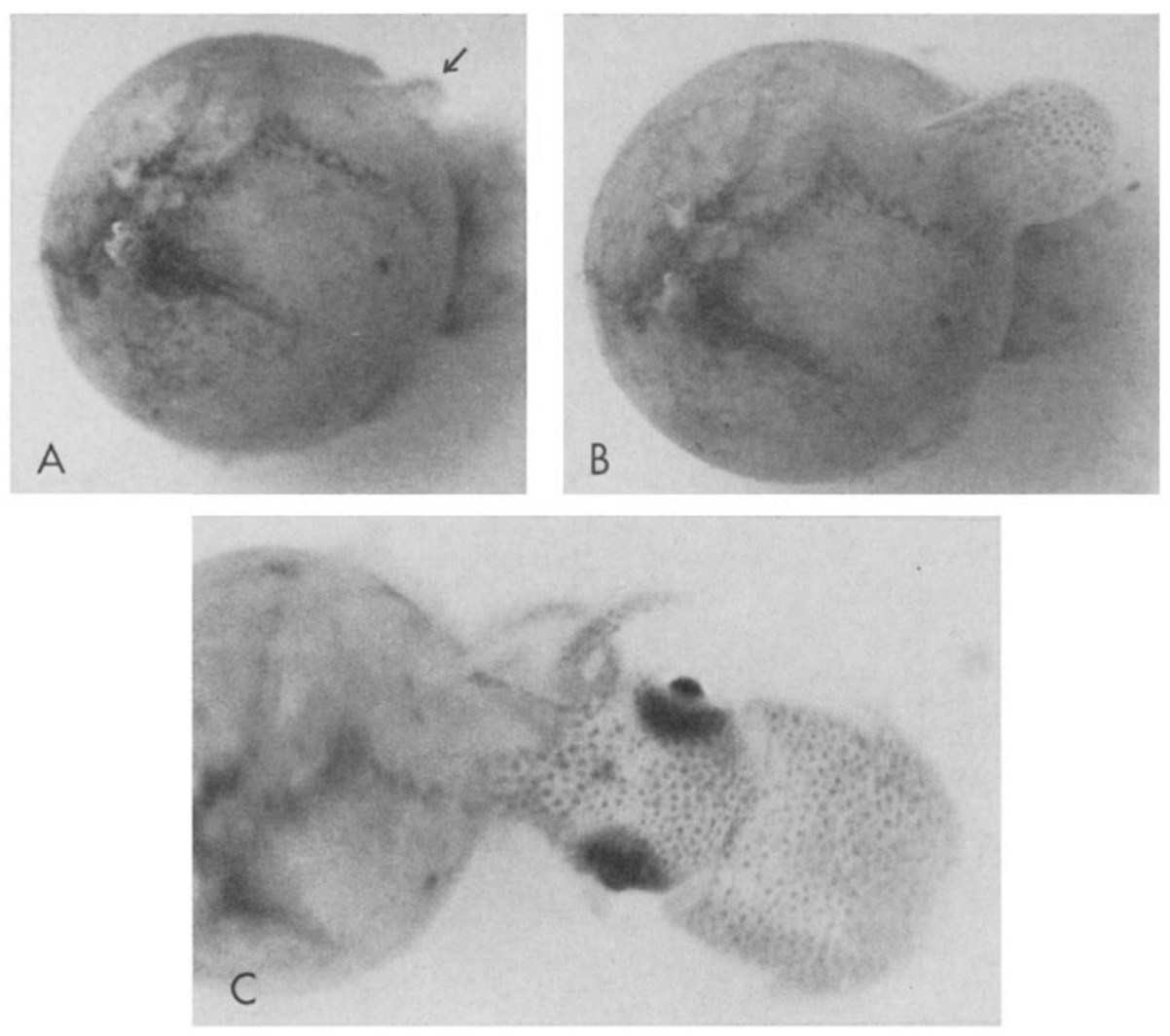

Fig. 14. Hatching of Rossia macrosoma. Arrow in $A$ points to mantle tip protruding from hatching slit. Within a few seconds thereafter, the animal had pushed its body through the opening $(B)$ and left the egg case $(C)$

gland is pressed against the envelope and perforates it by secretion of the "hatching enzyme". It takes about 10-20 seconds until all the layers of the envelope are locally dissolved so that the animal can work itself, by means of arm action and jet propulsion, through the hatch opening.

Under natural conditions, when the rigid outer egg case is intact, the animal breaks the latter, by pressing the mantle end with the "terminal spine" against it. The hatching gland may also have some function, in this last phase, by "preparing" the line of breaking, but breaking itself results from the pressure exerted by the mantle end with its "spine", the animal being able to press the arms against the opposite side of the rather narrow egg case (Fig. 14).

\section{Post-embryonic development}

Grow th. Newly hatched animals with a dorsal ML of $5 \mathrm{~mm}$ or more (hatching can take place prematurely at much smaller sizes) were placed in culture tanks with 
running sea water. They were fed live prawns (Leander serratus) of suitable size $(\sim 2 \times \mathrm{ML})$; in general they did not capture mysids; crabs, even very small specimens, were never eaten. Regular feeding (usually not more than 1 prawn/day) was observed from 8 to 10 days of age onward.

The maximal growth rate (Fig. 15) was obtained under the following conditions: Animals hatched from eggs that were raised at $15^{\circ} \mathrm{C}$ were reared at the same temperature, under "natural" light conditions (indirect daylight), with a rapid water

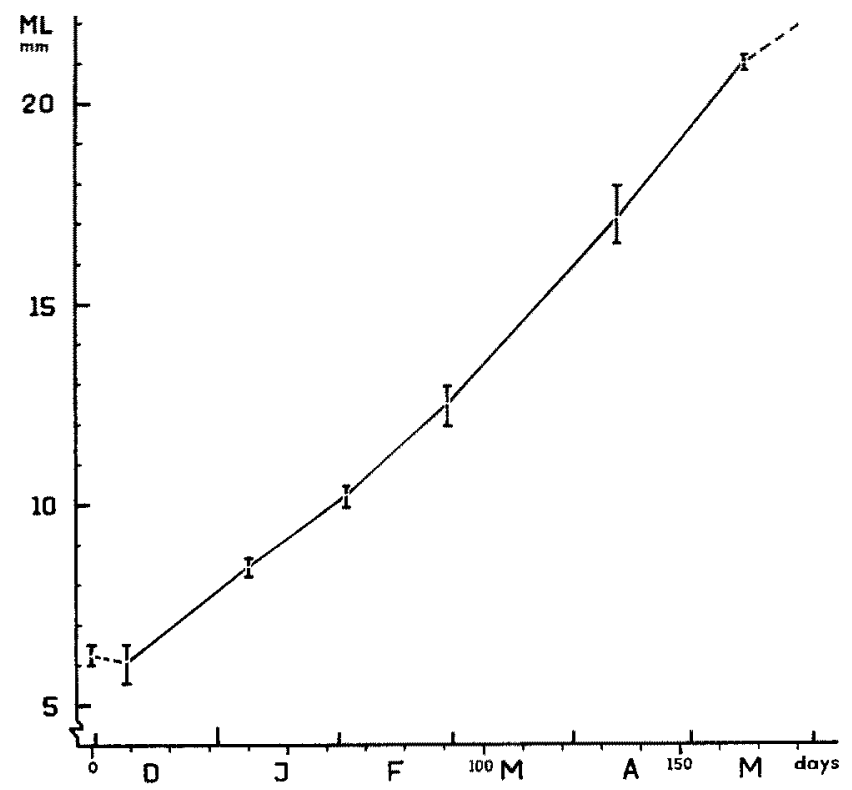

Fig. 15: Growth (increase in mantle length) of 3 Rossia macrosoma, raised at $15^{\circ} \mathrm{C}$ under "natural" light conditions (December to May). "The broken line for the first ten days represents the initial number of specimens; the broken line after 166 days indicates decreasing growth rate after transfer (see text)

exchange (water flow 3-5 $1 / \mathrm{min}$ ). Food was always present in overabundance. An empty Pinna shell placed in the tank served as a hiding place for Rossia (some of the prawns also retired there during day-time). Of 6 newly hatched animals, 2 died soon after hatching, another after about two months (starved for unknown reason). Figure 15 shows the growth of the three surviving animals; this curve corresponds to the growth rate observed in some Sepiolinae (BoLETzKY et al. 1971).

This experiment was interrupted by one of the (unfortunately frequent) breakdowns of the thermoregulator of the constant-temperature laboratory. After the animals were transferred to a culture room with higher water temperature and artificial light, feeding and growth slowed down and soon ceased completely. The last 2 animals died about 70 days later (aged 240 days), when the water temperature reached $22^{\circ} \mathrm{C}$, after 20 days with temperatures around $20^{\circ} \mathrm{C}$. 
At a constant temperature of $20^{\circ} \mathrm{C}$, under conditions otherwise identical to the $15^{\circ} \mathrm{C}$ experiment, survival was less than 40 days, despite feeding and growing.

Animals raised at environmental temperature $\left(19.5-13-22^{\circ} \mathrm{C}\right)$ with continuous lighting, showed rather steady growth at first (though slower than at constant $15^{\circ} \mathrm{C}$ ), but of 6 newly hatched animals, only one survived for more than 180 days; it also died (270 days of age, $20 \mathrm{~mm} \mathrm{ML}$ ) when the temperature rose to $22^{\circ} \mathrm{C}$ in late July.

The lowest temperatures that Rossia macrosoma may encounter in its natural habitat are probably around $12^{\circ} \mathrm{C}$. It is, therefore, not surprising that newly hatched animals kept at $8^{\circ}-9^{\circ} \mathrm{C}$ (daylight) did not feed and grow. However, of 6 animals,

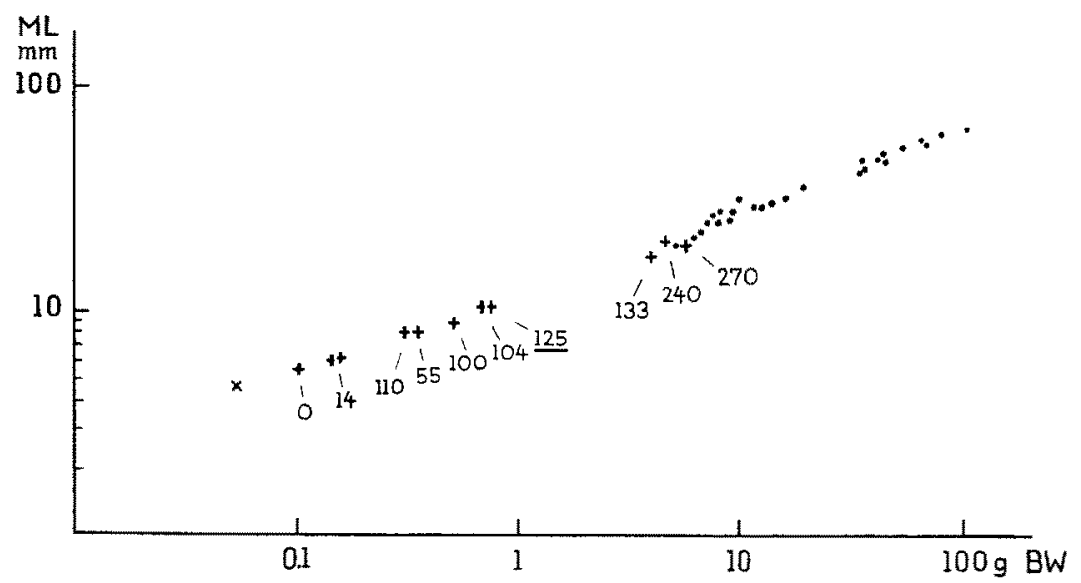

Fig. 16: Relationship between the dorsal mantle length and the body (wet) weight of Rossia macrosoma. $X$ marks prematurely hatched animal, + laboratory raised animals (with age in days); the animal measured at 125 days of age showed the typical signs of advanced starvation (see text). Animals captured from the sea are indicated by points

5 survived for nearly 80 days. Three animals remaining at 82 days of age were transferred to $15^{\circ} \mathrm{C}$, but they did not recover and died within 5 days. Histological sections of these animals showed that the inner yolk was almost entirely absorbed, but there was still the intact yolk syncytium lying between the lobes of the hepatopancreas, suggesting that yolk-absorption had slowly continued for almost 3 months after hatching.

Except for this last experiment (no feeding), we were not able to quantify food intake, so that we cannot say whether this is the only factor by which the growth rate of $R$. macrosoma is directly influenced (cf. MaNGold \& BoletzKy 1972).

A comparison with the growth rates of Sepiolinae would suggest that the highest rate observed in $R$. macrosoma can be considered as "normal" (cf. chapter "Discussion"). However, animals showing a much lower growth rate may also look quite healthy. They are easily distinguished from animals that are in an obvious starving condition (the cause of insufficient feeding is unknown).

Morphometrically, starved animals are characterized by a comparatively small palliovisceral complex and large eye bulbs; the mantle length thus tends to be smaller 

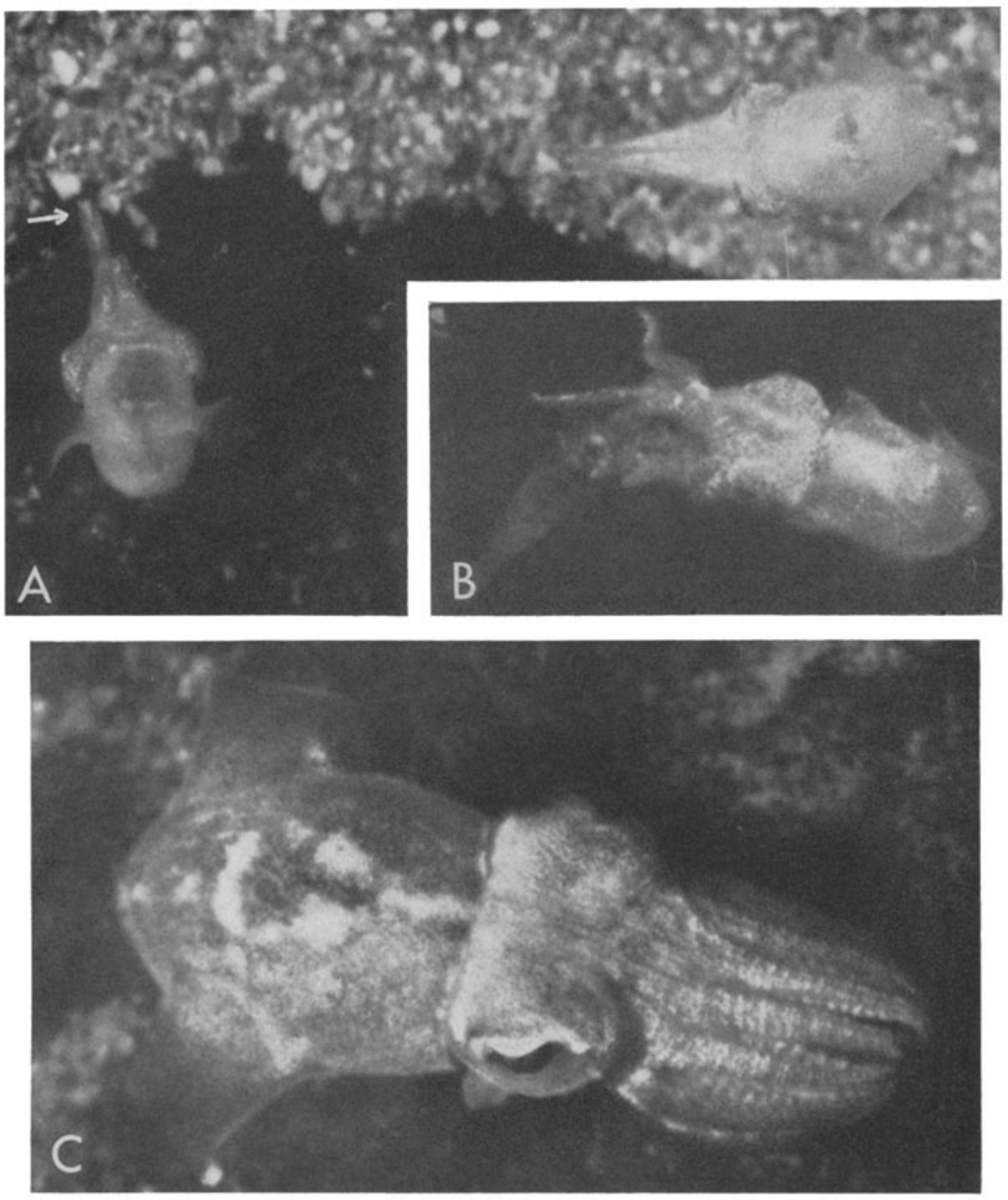

Fig. 17: Rossta macrosoma, raised in the laboratory. $A$ and $B$ : animals about 30 days of age, attacking prey ( $A$, arrow points to tentacles stretched out towards prey) and holding a prawn just captured $(B)$. C: an animal at 190 days of age, slowly swimming or "hovering"; the funnel tube is visible below the eye. Note the different phases, in $A, B$ and $C$, of the undulating movement of the fins

than the head width. The relationship between mantle length and body weight does not, therefore, express such a condition (Fig. 16).

A rough, but quite reliable indication of the physiological state of (at least younger) animals can be defined in terms of dorsal mantle length (ML), head width 
(HW) and diameter of eye bulbs (ED): "normal": $M L \geqq H W(H W \cong 3 \cdot E D)$; starving: $\mathrm{ML} \leqq \mathrm{HW}$; extreme starvation: $\mathrm{ML} \cong 2 \cdot \mathrm{ED}$.

Behaviour. Young Rossia macrosoma show a behaviour that is, in some respects, identical to that of Sepiolinae. They are very active swimmers using their fins when "hovering" in a nearly horizontal position that is partly maintained by the gentle water jet from the funnel. They shoot backward (e.g. escape) and rush forward (e.g. attack) by means of vigorous jet propulsion, their body sometimes taking a very slender shape. Predation (Fig. 17 A, B) is similar to what we observed in Sepiola and Sepietta (BOLETZKY et al. 1971), but an exact analysis equivalent to that carried out by Messenger (1968) with Sepia has not yet been made.

During the attacking of prey or in a state of (supposed) excitement, anteriorly directed waves of darkening may pass over the head and arms, as in Sepia. This is the most striking "pattern" based on chromatophore activity that we could observe in R. macrosoma. The white pattern that develops, in the early months after hatching, on the dorsal side of the mantle (Fig. 17), is a constant structure (concentration of iridocytes); it can only be "covered" by extreme chromatophore expansion.

When placed in a tank with a sand bottom, $R$. macrosoma does not regularly burrow as $R$. pacifica (Mather MS; Brocco, fide MATHER) and Sepiolinae do (BoLETZKY \& BOLETZKY 1970). In general, a few animals were found buried, while others had settled on the open sand or under a bivalve shell, again others were sitting attached (by arm suckers) to the wall of the tank, often close to the water surface, usually head down, the sitting position being as figured by RAcoviTzA (1894). They were often forming groups of about 5 to 10 animals. The behavioural pattern of burrowing, typical of $R$, pacifica (and possibly of other species) and of Sepiolinae is present in $R$. macrosoma. The first phase (whirling up sand by funnel jet) was observed once, with an animal sitting on the sand; this individual did not continue burrowing. The second phase (sweeping of dorso-lateral arms) was observed in an animal that was apparently much disturbed by being transferred from the tank to a glass jar; it went through the typical sweeping movement with the second pair of arms, while sitting on a hard bottom (this response to disturbance was also observed in Sepiolinae). Adult R. macrosoma captured from the sea are rarely seen buried in the sand of the aquarium.

A quite peculiar aspect is presented by young $R$. macrosoma crawling over a hard substratum, the arms being strongly extended (MATHER, MS). This kind of locomotion might suggest that the animals are particularly adapted to moving in very narrow passes that do not allow free swimming. The fact that they do not readily burrow in sand would also favour the idea that $R$. macrosoma, although apparently living on soft bottom (RACOVItZA 1894, MANGOLD-WIRZ 1963) and capable of burrowing, may prefer hiding in objects such as empty shells or in detritus.

\section{DISCUSSION}

In general, the length of embryonic development of cephalopods is understood as the time between fertilization or egg deposit and hatching. However, in Figure 4, 
hatching is not indicated by a well-defined end of the curve representing the course of development, but by a section of it, close to stage XX (disappearance of outer yolk sac). We do not yet know exactly the range of what can be considered as the period of "normal" hatching (in terms of the degree of yolk absorption), and we also ignore what triggers hatching.

In species with very large eggs such as Rossia macrosoma, in which embryonic growth may cover a long time before stage XX is attained, the period of supposedly normal hatching is also comparatively long. Besides the animals that hatch with a more or less sizable outer yolk sac, those must also be taken into account that remain in the egg case for some time after the disappearance of the outer yolk sac. When measuring the length of embryonic development, we must therefore differentiate between the two events "hatching" and "passing stage XX".

Another necessary separation is that between the length and the course of embryonic development. The latter is particularly important when the influence of temperature on the embryonic development is considered. The developmental rate, in different phases of embryonic development, cannot be extrapolated from the length of development measured at a certain temperature.

In his description of the embryonic development of cephalopods, NAEF (1928) placed special emphasis on the morphogenetic movements of the embryo, particularly on the contraction of the embryo cap during organogenesis. This must indeed be kept in mind when organogenetic processes are considered. Most of what seems, at first sight, to be directed growth then appears as combined tissue proliferation an $\mathrm{d}$ rearrangement (cf. Fig. 6). Directed growth also occurs, but always within rather narrow spatial limits.

By the contraction of the embryo (leading also to the compression of the inner yolk sac), organ rudiments not only take shape, but they are also closely packed together, in an arrangement that shows already the characteristics of definitive organisation. Subsequent growth then is a well-coordinated increase in size of organs in situ (including morphological modifications).

These processes are particularly important for the understanding of the organogenesis of the alimentary canal. Disregarding them necessarily results in erroneous descriptions, as recently demonstrated by MEISTER (1972) in a study on the organogenesis of Loligo; the fore-gut there appears as an extremely long ectodermic tube running across the embryo; the mid-gut complex (arising from an ectodermic rudiment, according to this author), after showing the actual clasp shape at stage $X$, apparently loses its dorsal processes, and the inner yolk sac is not compressed by it, but somehow retires between stages XI and XII, "providing ample space for further organ differentiation". We have already mentioned that the structure of the mid-gut rudiment was more correctly described by NAEF (1928), although he did not yet recognize its real extent and therefore figured the ectodermic fore-gut too long (NAEF 1928, Figs. 42, $50)$.

The evaluation of growth rates and age of $R$. macrosoma, based on field data, is very difficult because of a long breeding season and seasonal migrations (MANGoldWIRZ 1963). The few data we obtained with our rearing experiments do not provide very precise information, but they approach the values calculated by the afore- 
mentioned author. The highest growth rate we observed was an increase in ML of about $3.5 \mathrm{~mm} /$ month; this corresponds to the low rates calculated by MANGOLD-WIRZ for adult animals in which growth slows down. If we assume a 1-year cycle (spawning to spawning), the size of sexually mature animals must be attained within 8 to 9 months (after 3 to 4 months of embryonic development, if temperature is close to $15^{\circ} \mathrm{C}$ ); this supposes growth rates around $5 \mathrm{~mm} / \mathrm{month}$ in young animals. It is likely that such rates may be attained by Rossia, as they were observed in Sepietta (BoleTzky et al. 1971). We hope to be able to verify this in future experiments.

As with hatching, it remains to evaluate the natural variability. We do not yet know, whether, in the sea, animals that grow more slowly than the majority of their age class are eliminated, or whether such individuals survive and reproduce.

The observation that animals raised under unnatural light conditions (continuous lighting) showed slower growth than those exposed to a natural day/night cycle would rather suggest that (all healthy) Rossia macrosoma grow fast and steadily under entirely natural conditions. This idea is endorsed by our observations on Sepiola raised under experimental conditions (decreasing salinity, continuous or extremely short illumination) that resulted in a divergency of the individual growth rates, while these were always high (sometimes identical) among animals raised under "natural" conditions.

\section{SUMMARY}

1. Egg masses of Rossia macrosoma were collected by bottom trawling in the Western Mediterranean. The ultrastructure of the peculiar outer case of the egg is described.

2. The embryonic development was followed at a constant temperature $\left(15^{\circ} \mathrm{C}\right)$; a graphic presentation of developmental rates throughout the embryogenesis is given. Problems concerning the length and the course of embryonic development are discussed.

3. Embryogenesis is briefly described and figured. A few remarks are made on the organogenesis of the arm-funnel complex, the alimentary canal, the shell sac and the vena cava. Emphasis is placed on the dynamics of embryogenesis.

4. The mechanism of yolk absorption during later embryonic development includes collecting and transfer (to the hepatopancreas) of nutritive material by means of the yolk "vessels" (former yolk sinus).

5. For hatching, the secretory action of the Hoyle organ is followed by breaking the outer egg case, which is possibly facilitated by the muscular mantle "spine".

6. Hatched animals were raised in the laboratory for several months, under varying conditions. The observations on growth and behaviour are discussed, earlier observations and field data being considered.

Acknowledgements. The electron micrographs were taken at the "Laboratoire de Microscopie électronique du C.N.R.S., Paris"; the hospitality offered by the Director, Prof. Dr. R. COUTEAUX, and the technical assistance of the staff are gratefully acknowledged. We also thank Dr. K. MANGold and Dr. H. J. Marthy, of the Laboratoire Arago, for critically reading the manuscript and for valuable suggestions. 
Abbreviations used in figures

$\begin{array}{ll}\text { a: } & \text { arm } \\ \text { bh: } & \text { branchial heart } \\ \text { bd: } & \text { blastodisc } \\ \text { co: } & \text { coecum } \\ \text { e: } & \text { eye } \\ \text { f: } & \text { fin } \\ \text { fo: } & \text { funnel organ } \\ \text { fp: } & \text { funnel pocket } \\ \text { fr: } & \text { funnel retractor } \\ \text { fu: } & \text { funnel } \\ \mathrm{g}: & \text { gill } \\ \text { go: } & \text { gonad } \\ \text { h: } & \text { systematic heart } \\ \text { ho: } & \text { Hoyle's organ } \\ \text { hp: } & \text { hepatopancreas } \\ \mathrm{i}: & \text { intestine } \\ \mathrm{k}: & \text { kidney } \\ \mathrm{kp}: & \text { kidney papilla }\end{array}$

$\begin{array}{ll}\text { m: } & \text { mantle } \\ \text { ms: } & \text { mantle septum } \\ \text { mo: } & \text { mouth } \\ \text { o: } & \text { olfactory tuberculum } \\ \text { oe: } & \text { oesophagus } \\ \text { pc: } & \text { pericardium } \\ \text { pl: } & \text { primary lid } \\ \text { s: } & \text { sucker } \\ \text { sc: } & \text { statocyst } \\ \text { se: } & \text { shell epithelium } \\ \text { sg: } & \text { salivary gland } \\ \text { sh: } & \text { shell sac } \\ \text { st: } & \text { stomodaeum } \\ \text { stg: } & \text { stellate ganglion } \\ \text { t: } & \text { tentacle } \\ \text { vc: } & \text { vena cava } \\ \text { y: } & \text { yolk } \\ \text { ye: } & \text { yolk envelope }\end{array}$

\section{LITERATURE CITED}

ARnold, J. M., 1965a. Normal embryonic stages of the squid, Loligo pealii (LeSueur). Biol. Bull. mar. biol. Lab., Woods Hole 128, 24-32.

- 1965b. The inductive role of the yolk epithelium in the development of the squid, Loligo pealii (LeSueur). Biol. Bull. mar. biol. Lab., Woods Hole 129, 72-78.

- 1968. The role of the egg cortex in cephalopod development. Devl. Biol. 18, 180-197.

- Singley, C. T. \& Wilitams-Arnold, L. D., 1972. Embryonic development and posthatching survival of the sepiolid squid Euprymna scolopes under laboratory conditions. Veliger 14, 361-364.

BolETZKY, S. yoN, 1964. Uber die embryonale Entwicklung der Schalendrüse bei Sepia officinalis, Sepiola sp., Loligo vulgaris und Octopuss vulgaris. Unpubl. rep.

- 1967. Die embryonale Ausgestaltung der frühen Mitteldarmanlage von Octopus vulgaris LAM. Revue suisse Zool. 74, 555-562.

- 1968. Untersuchungen über die Organogenese des Kreislaufsystems von Octopus vulgaris Lam. Revue suisse Zool. 75, 765-812.

- 1970a. Biological results of the Miami Deep-Sea Expeditions. 54: On the presence of light organs in Semirossia Steenstrup, 1887 (Mollusca: Cephalopoda). Bull. mar. Sci. 20, 374-388.

- 1970b. On the lay-out of the midgut rudiment in Loligo pealei (LESUEUR). Experientia 26, $880-881$.

- 1971. Neorossia, n.g. pro Rossia caroli Joubrn, 1902, with remarks on the generic status of Semirossia SteEnstrup, 1887 (Mollusca: Cephalopoda). Bull. mar. Sci. 21, 964-969.

- \& Boletzky, M. V. von, 1970. Das Eingraben in Sand bei Sepiola und Sepietta (Mollusca, Cephalopoda). Revue suisse Zool. 77, 536-548.

- - Frösch, D. \& GäTzı, V., 1971. Laboratory rearing of Sepiolinae (Mollusca: Cephalopoda). Mar. Biol. 8, 82-87.

CHOE, S., 1966. On the growth, feeding rates and the efficiency of food conversion for cuttlefishes and squids. Korean J. Zool. 9, 12-20.

FreLDs, W. G., 1965. The structure, development, food relations, reproduction and life history of the squid Loligo opalescens Berry. Fish. Bull. Calif. 131, 1-108. 
Froroni, P., 1962. Die embryonale Entwicklung der Hautdrüsen und des Trichterorgans von Octopus vulgaris LAM. Acta anat. 50, 264-295.

- 1964. Zum embryonalen Größenwachstum bei Tintenfischen. Revue suisse Zool. 71, 777-804.

JECKLIN, L., 1934. Beitrag zur Kenntnis der Laichgallerten und der Biologie der Embryonen decapoder Cephalopoden. Revue suisse Zool. 41, 593-673.

Konopackr, M., 1933. Histophysiologie du développement de Loligo vulgaris. Bull. int. Acad. pol. Sci. Lett. (B) 11, 51-69.

KorschelT, E., 1892. Beiträge zur Entwidklungsgeschichte der Cephalopoden. In: Festschrift zum 70. Geburtstag R. LeUckArTs. Engelmann, Leipzig, 347-373.

Lemaire, J., 1970. Table de développement embryonnaire de Sepia officinalis L. (Mollusque Céphalopode). Bull. Soc. zool. Fr. 95, 773-782.

Mangold, K. \& Boletzky, S. von, 1972. New data on reproductive biology and growth of Octopus vulgaris. Mar. Biol. 19, 7-12.

MANGold-WIRz, K., 1963. Biologie des céphalopodes benthiques et nectoniques de la Mer Catalane. Vie Milieu (Suppl.) 13, 1-285.

Marthy, H. J., 1972a. Sur la localisation et la stabilité du plan d'ébauches d'organes hez l'embryon de Loligo vulgaris (Mollusque Céphalopode). C. R. hebd. Séanc. Acad. Sci., Paris 275, 1291-1293.

- 1972b. An experimental study of eye development in the cephalopod Loligo vulgaris: determination and regulation during formation of the primary optic vesicle. J. Embryol. exp. Morph. 29, 347-361.

MatHer, J. Rossia pacifica behavior. MS.

Meister, G., 1972. Organogenese von Loligo vulgaris Lam. (Mollusca, Cephalopoda, Teuthoidea, Myopsida, Loliginidae). Zool. Jb. (Anat. Ontogenie Tiere) 89, 247-300.

Messenger, J. B., 1968. The visual attack of the cuttlefish, Sepia officinalis. Anim. Behav. 16, $342-357$.

NAEF, A., 1910. Zur vergleichenden Anatomie und Entwicklungsgeschichte des Blutgefäßsystems der Cephalopoden. Zool. Anz. 36, 316-329.

- 1923. Die Cephalopoden. Fauna Flora Golf. Neapel 35 (1), V-XIV, 1-863.

- 1928. Die Cephalopoden. Fauna Flora Golf. Neapel 35 (2), V-IX, 1-357.

NATSUKARI, Y, 1970. Egg-laying behavior, embryonic development and hatched larva of the pygmy cuttlefish, Idiosepius pygmaeus paradoxus OrTManN. Bull. Fac. Fish. Nagasaki Univ. 30, 15-29.

Orexzr, M. von, 1959. Ober das Schlïpfen von Octopus vulgaris, Sepia officinalis und Loligo vulgaris. Revue suisse Zool. 66, 330-343.

Portmann, A., 1926. Der embryonale Blutkreislauf und die Dotterresorption bei Loligo vulgaris. Z. Morph. Ókol. Tiere 5, 406-423.

- \& Bidder, A. M., 1929. Yolk-absorption and the function of the embryonic liver and pancreas. Q. Jl microsc. Sci. 72, 301-324.

RacovitzA, E. G., 1894. Notes de biologie II. Moeurs et reproduction de la Rossia macrosoma (D. Ch.). Archs Zool. exp. gén. 2, 491-539.

SACARRAo, G. F., 1956. Sobre a evolução ontogenética das relaçōes embriāo-órgão vitelino nos Cefalópodos. Archos Mus. Bocage 26, 1-126.

SprEss, P. E., 1972. Organogenese des Schalendrüsenkomplexes bei einigen coleoiden Cephalopoden des Mittelmeeres. Revue suisse Zool. 79, 167-226.

WINTREBERT, P., 1928. L'éclosion par digestion de la coque chez les poissons, les amphibiens et les céphalopodes dibranchiaux décapodes. C. r. Ass. Anat. 1928, 501-503.

First author's address: Dr. S. von BoLETZKY

Laboratoire Arago

F-66650-Banyuls-sur-Mer

France 